\title{
RELATIONSHIP BETWEEN PARENTS 'ATTENTION, SOCIAL ENVIRONMENT, AND INDEPENDENCE LEARNING WITH MATHEMATICAL LEARNING OUTRCOME OF STUDENTS IN SMP MUHAMMADIYAH 9 YOGYAKARTA
}

\author{
Lutfi Azmul Fauzia ${ }^{\mathrm{a}}$, Abdul Taram ${ }^{\mathrm{b}}$ \\ Program Studi Pendidikan Matematika Universitas Ahmad Dahlan \\ Jalan Ring Road Selatan, Tamanan, Banguntapan, Bantul Yogyakarta \\ a $\underline{\text { lutfi12006204@gmail.com, }}{ }^{\mathrm{b}}$ taram@uad.ac.id
}

\begin{abstract}
The low student mathematics learning outcomes are influenced by many factors. Parental attention, social environment, and learning independence are some of the factors that are thought to influence student learning outcomes in mathematics. Therefore, this study was conducted with the aim of finding out whether there was a positive and significant relationship between parents' attention, social environment and learning independence with mathematics learning outcomes for students of class VIII odd semester of SMP Muhammadiyah 9 Yogyakarta 2016/2017 school year. The population in this study were all eighth-grade students of Muhammadiyah 9 Yogyakarta Middle School 2016/2017 academic year consisting of 5 classes with a total of 182 students. As the sample class VIII D consisting of 36 students using random sampling techniques to the class. The data collection technique was carried out using a questionnaire method for parents' attention, social environment and learning independence. As for the test method for student mathematics learning outcomes. The instrument test uses validity and reliability tests. The analysis prerequisite test uses a normality test, independent test, and linearity test. Analysis of hypothesis testing data uses simple linear regression analysis and multiple regression and correlation analysis. The results showed that there is a positive and significant correlation among parents' attention, social environment and learning independence with mathematics learning outcomes with $\mathrm{F}_{\text {count }}=9,70>\mathrm{F}_{\text {table }}=2,90$ multiple correlation coefficient $(\mathrm{R})$ is 0,69 and the multiple determination coefficient $\left(R^{2}\right)$ is 0,48 . While the multiple regression equation is $\hat{Y}=-95,97+$ $0,83 X_{1}+0,41 X_{2}+0,68 X_{3}$, relatively contribution $\left(X_{1}\right)=62,34 \%$, the relative contribution $\left(\mathrm{X}_{2}\right)=$ $19,18 \%$, the relative contribution $\left(X_{3}\right)=18,48 \%$ and effective contribution $\left(X_{1}\right)=29,68 \%$, the effective contribution $\left(X_{2}\right)=9,13 \%$, and the effective contribution $\left(X_{3}\right)=8,80 \%$.
\end{abstract}

Keywords: Parents' attention, social environment, learning independence, mathematics learning outcomes.

\section{INTRODUCTION}

Education is a determinant for the progress of a country in the future. With education, every individual is expected to participate in development so as to improve the quality of their existence. Therefore, good quality education is emphasized in order to produce quality Human Resources (HR). Education in Indonesia is currently demanded to be able to produce quality Human Resources (HR), namely human resources capable of competing in the current era of globalization. To fulfill this, education today must be more creative by being able to create an environment (both formal, non-formal and informal) that is fun for students.

Mathematics is one of the most important sciences because every individual always uses mathematical concepts and calculations in his activities. In addition, mathematics is also very important in the development of technology today. Therefore, mathematics is taught from the earliest level of informal education in Indonesia. However, this contrasts strongly with students' interest in learning mathematics. This is because mathematics is one of the subjects that is considered difficult. Even in Indonesia, there is an opinion that smart children are children with good mathematical grades. This shows that mathematics is indeed a subject that is feared and considered difficult. Difficulty in learning mathematics can also be seen from the low student mathematics learning outcomes. Indicators of low mathematics learning outcomes are evident from the documentation of the scores of the Even Semester 
Final Exams obtained by students of Class VII of SMP Muhammadiyah 9 Yogyakarta 2015/2016 Academic Year. Final semester exam scores (UAS) are shown in Table 1.

Table 1. Final Semester (UAS) Mathematics Test Grade VII Even Semester, SMP Muhammadiyah 9 Yogyakarta Academic Year 2015/2016

\begin{tabular}{lccccc}
\hline \multicolumn{1}{c}{ Class } & VII A & VII B & VII C & VII D & VII E \\
\hline Average & 68,27 & 68,32 & 67,72 & 66,75 & 58,72 \\
The highest score & 84 & 90 & 80 & 80 & 84 \\
Lowest Value & 52 & 55 & 60 & 55 & 45 \\
> KKM & 21 & 17 & 16 & 16 & 4 \\
< KKM & 16 & 18 & 21 & 20 & 33 \\
\hline
\end{tabular}

(Source: SMP Muhammadiyah 9 Yogyakarta Tahun Ajaran 2015/2016)

From Table 1 shows that the average value of the Final Examination Semester (UAS) of Mathematics for Class VII Even Semester of Muhammadiyah 9 Yogyakarta Junior High School has not reached the Minimum Mastery Criteria (KKM), which is 70,307. This proves that some students still experience difficulties in learning mathematics. Apart from parents' attention and social environment, another factor is the lack of student learning independence at Yogyakarta Muhammadiyah 9 Middle School which is still lacking. For example in teaching and learning activities when children have difficulties, children are reluctant to ask the teacher. In addition, the independence of students in doing assignments is also still lacking. Students who are less independent will cheat on their friends, even though cheating students will only write without knowing how to do it. Walgito, Bimo (1986: 127-128) explains that forms of parents' attention include providing children's learning facilities and helping learning activities child. Kulsum, Umi and Mohammad Johar (2014: 69-70) argue that the social environment is a medium in which living things live, find their livelihoods, and have distinctive characters and functions which are reciprocally related to the existence of living things that inhabit them. In other words, humans cannot live alone without the help of other humans. According to Lerner in Nurhayati, Eti (2011: 131) independence refers to psychosocial abilities, which include freedom to act, are not dependent on others, are not affected by the environment, and are free to regulate their own needs.

Based on the description above, the problems that can be taken in this study are

1. Is there a positive and significant relationship between parents' attention and mathematics learning outcomes of Grade VIII odd semester students of SMP Muhammadiyah 9 Yogyakarta 2016/2017 Academic Year?

2. Is there a positive and significant relationship between the social environment and mathematics learning outcomes of students of class VIII Odd Semester of Muhammadiyah 9 Yogyakarta Middle School 2016/2017 Academic Year?

3. Is there a positive and significant relationship between learning independence and mathematics learning outcomes of students of class VIII Odd Semester of Muhammadiyah 9 Yogyakarta Middle School 2016/2017 Academic Year?

4. Is there a positive and significant relationship between parents' attention and the social environment with the mathematics learning outcomes of Grade VIII odd semester students of SMP Muhammadiyah 9 Yogyakarta 2016/2017 Academic Year?

5. Is there a positive and significant relationship between parents' attention and independence of learning with mathematics learning outcomes of students of class VIII Odd Semester of Muhammadiyah 9 Yogyakarta Middle School 2016/2017 Academic Year?

6. Is there a positive and significant relationship between the social environment and learning independence with mathematics learning outcomes of students of class VIII Odd Semester of Muhammadiyah 9 Yogyakarta Middle School 2016/2017 Academic Year? 
7. Is there a positive and significant relationship between parents' attention, social environment and learning independence with mathematics learning outcomes of students of class VIII Odd Semester of Muhammadiyah 9 Yogyakarta Middle School 2016/2017 Academic Year?

The objectives to be achieved in this study based on existing problems are as follows

1. To find out whether or not there is a positive and significant relationship between parents' attention and mathematics learning outcomes of Grade VIII odd semester students of SMP Muhammadiyah 9 Yogyakarta 2016/2017 Academic Year.

2. To find out whether or not there is a positive and significant relationship between the social environment and mathematics learning outcomes of Grade VIII odd semester students of SMP Muhammadiyah 9 Yogyakarta 2016/2017 Academic Year.

3. To find out whether or not there is a positive and significant relationship between learning independence and mathematics learning outcomes of Grade VIII odd semester students of SMP Muhammadiyah 9 Yogyakarta 2016/2017 Academic Year.

4. To find out whether or not there is a positive and significant relationship between parents' attention and social environment with the mathematics learning outcomes of Grade VIII odd semester students of SMP Muhammadiyah 9 Yogyakarta 2016/2017 Academic Year.

5. To find out whether or not there is a positive and significant relationship between parents' attention and learning independence with mathematics learning outcomes of Grade VIII odd semester students of SMP Muhammadiyah 9 Yogyakarta 2016/2017 Academic Year.

6. To find out whether or not there is a positive and significant relationship between social environment and learning independence with mathematics learning outcomes of students of class VIII Odd Semester of Muhammadiyah 9 Yogyakarta Middle School 2016/2017 Academic Year.

7. To find out whether or not there is a positive and significant relationship between parents' attention, social environment and learning independence with mathematics learning outcomes for students of class VIII Odd Semester of Muhammadiyah 9 Yogyakarta Middle School 2016/2017 Academic Year.

\section{METHODS}

This study is classified as a quantitative study conducted at SMP Muhammadiyah 9 Yogyakarta, students of class VIII odd semester of the 2016/2017 school year. The population in this study were all students of class VIII odd semester of Muhammadiyah 9 Yogyakarta Middle School 2016/2017 academic year consisting of 5 classes. Whereas for sampling the random sampling technique was used in class and class VIII D was taken as a sample class consisting of 36 students. Then for the pilot class is class VIII A with the number of students 37. In this study, there are three independent/independent variables namely Parental Attention $\left(\mathrm{X}_{1}\right)$, Social Environment $\left(\mathrm{X}_{2}\right)$, and Learning Independence $\left(\mathrm{X}_{3}\right)$. Whereas the dependent variable is Student Mathematical Learning Outcomes (Y). Data collection is done by using a questionnaire (questionnaire) and test methods. The questionnaire method used in this study is a closed questionnaire to obtain data about parents' attention, social environment, and learning independence. Then the test method used to obtain student learning outcomes in mathematics class VIII Odd Semester SMP Muhammadiyah 9 Yogyakarta Academic Year 2016/2017 with the subject of Algebra. In this study, the validity used is content validity. To determine the validity of each item, an instrument can be tested using the Content Validity Test of the contents and shape of the instrument according to certain criteria by reviewers. The technique used to determine the validity of the question item is by using the product-moment correlation technique with the following formula:

$$
r_{x y}=\frac{N \sum X Y-\left(\sum X\right)\left(\sum Y\right)}{\sqrt{\left\{N \sum X^{2}-\left(\sum X\right)^{2}\right\}} \sqrt{\left\{N \sum Y^{2}-\left(\sum Y\right)^{2}\right\}}}
$$

(Arikunto, Suharsimi. 2012:87)

The formula used for the different power tests is as follows: $D=\frac{B_{A}}{J_{A}}-\frac{B_{B}}{J_{B}}=P_{A}-P_{B}$ 
(Arikunto, Suharsimi. 2012:228)

To determine the consistency of instrument reliability in the form of a questionnaire used internal consistency by calculating the instrument reliability coefficient through the Alpha formula, namely:

$$
r_{11}=\left(\frac{n}{n-1}\right)\left(1-\frac{\sum_{i=1}^{n} \sigma_{i}^{2}}{\sigma_{j}^{2}}\right)
$$

(Arikunto, Suharsimi. 2012:122)

The reliability testing of the student mathematics learning outcomes instrument uses the KR-20 formula as follows:

$$
r_{11}=\frac{n}{n-1}\left(\frac{S^{2}-\sum_{i=1}^{n} p q}{S^{2}}\right)
$$

(Arikunto, Suharsimi. 2012:115)

After the data is collected, the next stage of the analysis prerequisite test includes the normality test, independent test, and linearity test. To test the hypothesis used t-test and F-test. For the t-test you can use the formula:

$$
t=\frac{r \sqrt{n-2}}{\sqrt{1-r^{2}}}
$$

(Sudjana. 2005: 377)

Whereas the F-test can use the formula:

$$
F=\frac{R^{2}(n-k-1)}{\left(1-R^{2}\right) k}
$$

(Sudjana. 2005: 385)

\section{RESULTS AND DISCUSSION}

The first hypothesis test result is that there is a positive and significant relationship between parents' attention and mathematics learning outcomes. In this study, a simple correlation coefficient $(r)$ of 0.58 was obtained at a significant level of $5 \%$ and $\mathrm{df}=34$. So that the determinant coefficient $\left(\mathrm{r}^{2}\right)$ was obtained of 0.34 which can be explained that $34 \%$ of learning outcomes are influenced by people's attention while the rest is influenced by other factors. This can be explained through the linear relationship $\hat{Y}=-20,27+0,96 X_{1}$ with a regression coefficient of 0.96 . This means that every increase of one unit $\mathrm{X}_{1}$ results in 0.96 increase in Y. From the results of this calculation, it can be seen that with increasing parents' attention the student's mathematics learning outcomes will be even better, and vice versa.

The second hypothesis test result is that there is a positive and significant relationship between the social environment and mathematics learning outcomes. In this study, a simple correlation coefficient $(r)$ was obtained at 0.45 at a significant level of $5 \%$ and $\mathrm{df}=34$. So that the determinant coefficient $\left(r^{2}\right)$ was obtained that was 0.20 which can be explained that $20 \%$ of learning outcomes are influenced by the social environment while the rest is influenced by other factors. This can be explained through the linear relationship $\widehat{Y}=-13,91+0,90 X_{2}$, with a coefficient of regression direction of 0.90 . This means that each increase in one unit of $X_{2}$ results in 0.90 increase in Y. From the results of this calculation it can be seen that with the increase in the social environment, student mathematics learning outcomes will be even better, and vice versa.

The third hypothesis test results are that there is a positive and significant relationship between learning independence with mathematics learning outcomes. In this study, a simple correlation coefficient $(r)$ of 0.32 was obtained at a significant level of $5 \%$ and $\mathrm{df}=34$. So that the determinant coefficient $\left(r^{2}\right)$ was obtained for 0.10 which can be explained that $10 \%$ of learning outcomes are influenced by learning independence while the rest is influenced by other factors. This can be explained through the linear relationship $\hat{Y}=-6,91+0,77 X_{3}$, with a coefficient of regression direction of 0.77 . This means that each increase in one unit of $\mathrm{X}_{3}$ results in 0.77 increase in $\mathrm{Y}$. From the results of this 
calculation it can be seen that with the increase in the independence of learning, student mathematics learning outcomes will be better, and vice versa.

The fourth hypothesis test result is that there is a positive and significant relationship between parents' attention and social environment with mathematics learning outcomes. In this study, a multiple correlation coefficient $(\mathrm{R})$ of 0.63 and a determinant coefficient $\left(\mathrm{R}^{2}\right)$ of 0.40 can be explained that $40 \%$ of learning outcomes are influenced by parents' attention and social environment while the rest are influenced by other factors. This can be explained through the linear relationship $\hat{Y}=-47,76+$ $0,79 X_{1}+0,53 X_{2}$. This means that every increase of one unit $X_{1}$ results in 0.79 increase in $Y$ and an increase in one unit $\mathrm{X}_{2}$ results in 0.53 increase in $\mathrm{Y}$, in other words, if the attention of parents and social environment is high, the students' mathematics learning outcomes will increase, and vice versa. As for the relative contribution of $X_{1}$ by $70.60 \%$ and $X_{2}$ by $29.40 \%$ and the effective contribution of $X_{1}$ by $28.34 \%$ and $\mathrm{X}_{2}$ by $11.80 \%$.

The fifth hypothesis test results are that there is a positive and significant relationship between parents' attention and learning independence with mathematics learning outcomes. In this study, a multiple correlation coefficient (R) of 0.66 and a determinant coefficient $\left(R^{2}\right)$ of 0.44 can be explained that $44 \%$ of learning outcomes are influenced by parents' attention and learning independence while the rest is influenced by other factors. This can be explained through the linear relationship Y $\hat{Y}=$ $-81,96+0,96 X_{1}+0,77 X_{3}$. This means that each increase of one unit $X_{1}$ results in a 0.96 increase in $\mathrm{Y}$ and an increase in one unit $\mathrm{X}_{3}$ results in 0.77 increase in $\mathrm{Y}$, in other words, if the attention of parents and high learning independence, then student mathematics learning outcomes will increase, and vice versa. As for the relative contribution of $X_{1}$ by $77.43 \%$ and $X_{3}$ by $22.57 \%$ and the effective contribution of $\mathrm{X}_{1}$ by $34.22 \%$ and $\mathrm{X}_{3}$ by $9.98 \%$.

The sixth hypothesis test results are that there is a positive and significant relationship between the social environment and learning independence with mathematics learning outcomes. In this study, a multiple correlation coefficient $(\mathrm{R})$ of 0.51 and a determinant coefficient $\left(R^{2}\right)$ of 0.26 can be explained that $26 \%$ of learning outcomes are influenced by the social environment and learning independence while the rest is influenced by other factors. This can be explained through the linear relationship $\hat{Y}=$ $-54,32+0,81 X_{2}+0,59 X_{3}$. This means that each increase of one unit $X_{2}$ results in a 0.81 increase in $\mathrm{Y}$ and an increase in one unit $\mathrm{X}_{3}$ results in 0.59 increase in $\mathrm{Y}$, in other words, if the social environment and high learning independence, then the results of student mathematics learning will increase, and vice versa. As for the relative contribution of $X_{2}$ by $70.31 \%$ and $X_{3}$ by $29.69 \%$ and the effective contribution of $\mathrm{X}_{2}$ by $18.08 \%$ and $\mathrm{X}_{3}$ by $7.63 \%$.

The seventh hypothesis test result is that there is a positive and significant relationship between parents' attention, social environment, and learning independence with mathematics learning outcomes. In this study, a multiple correlation coefficient $(\mathrm{R})$ of 0.69 was obtained. This can be explained through the linear relationship $\hat{Y}=-95,97+0,83 X_{1}+0,41 X_{2}+0,68 X_{3}$. This means that each increase of one unit $\mathrm{X}_{1}$ results in 0.83 increase in $\mathrm{Y}$, an increase in one unit $\mathrm{X}_{2}$ results in 0.41 increase in $\mathrm{Y}$, and an increase in one unit $\mathrm{X}_{3}$ results in 0.68 increase in $\mathrm{Y}$, in other words if the attention of parents, social environment, and learning independence high, then student mathematics learning outcomes will increase, and vice versa. As for the relative contribution of $X_{1}$ by $62.34 \%, X_{2}$ by $19.18 \%$, and $X_{3}$ by $18.48 \%$ and the effective contribution of $\mathrm{X}_{1}$ by $29.68 \%, \mathrm{X}_{2}$ by $9.13 \%$, and $\mathrm{X}_{3}$ by $8.80 \%$. This shows that parents' attention gives a more significant relationship to mathematics learning outcomes than the social environment and learning independence. The determinant coefficient $\left(\mathrm{R}^{2}\right)$ of 0.48 means that student mathematics learning outcomes are influenced by parents' attention, social environment and learning independence by $48 \%$ while $52 \%$ is influenced by other factors not discussed in this study.

After it is known that parents' attention, social environment, and learning independence have positive and significant effects on student mathematics learning outcomes. This means that the increase and decrease in student mathematics learning outcomes are related to parents' attention, social environment, and good or not independent learning. Therefore it is expected that various parties can optimize their role in improving mathematics learning outcomes. 


\section{CONCLUSION}

Based on the results of research and discussion, several research conclusions can be drawn as follows:

1. There is a positive and significant relationship between parents' attention and mathematics learning outcomes of students of class VIII odd semester of SMP Muhammadiyah 9 Yogyakarta 2016/2017 Academic Year. This is indicated by the test ( $\mathrm{t}$ ), that is $t_{\text {count }}=4,20>t_{\text {table }}=1,69$. Simple correlation coefficient $(\mathrm{r})$ between parents' attention $\left(\mathrm{X}_{1}\right)$ with mathematics learning outcomes $(\mathrm{Y})$ of 0.58 with a linear regression equation $\hat{Y}=-20,27+0,96 X_{1}$.

2. There is a positive and significant relationship between the social environment and mathematics learning outcomes of students of class VIII Odd Semester, SMP Muhammadiyah 9 Yogyakarta 2016/2017 Academic Year. This is indicated by the test $(\mathrm{t})$, that is $t_{\text {count }}=2,92>t_{\text {table }}=1,69$. Simple correlation coefficient $(\mathrm{r})$ between social environment $\left(\mathrm{X}_{2}\right)$ with mathematics learning outcomes (Y) of 0.45 with a linear regression equation $\hat{Y}=-13,91+0,90 X_{2}$.

3. There is a positive and significant relationship between learning independence with mathematics learning outcomes for students of class VIII Odd Semester of SMP Muhammadiyah 9 Yogyakarta $2016 / 2017$ Academic Year. This is indicated by the test $(\mathrm{t})$, that is $t_{\text {count }}=1,94>t_{\text {table }}=1,69$. Simple correlation coefficient (r) between learning independence $\left(\mathrm{X}_{3}\right)$ and mathematics learning outcomes (Y) of 0.32 with a linear regression equation $\hat{Y}=-6,91+0,77 X_{3}$.

4. There is a positive and significant relationship between parents' attention and the social environment with the mathematics learning outcomes of students of class VIII Odd Semester of SMP Muhammadiyah 9 Yogyakarta 2016/2017 Academic Year. This is indicated by the F test, that is $F_{\text {count }}=11,06 \geq F_{\text {table }}=3,28$. The multiple correlation coefficient (R) of 0.63 with a linear regression equation $\hat{Y}=-47,76+0,79 X_{1}+0,53 X_{2}$. The relative contribution of $\mathrm{X} 1$ is $70.60 \%$ and $X_{2}$ is $29.40 \%$ and the effective contribution $X_{1}$ is $28.34 \%$ and $X_{2}$ is $11.80 \%$.

5. There is a positive and significant relationship between parents' attention and learning independence with mathematics learning outcomes of Grade VIII odd semester students of SMP Muhammadiyah 9 Yogyakarta 2016/2017 Academic Year. This is indicated by the F test, that is $F_{\text {count }}=13,07 \geq F_{\text {table }}=3,28$. The multiple correlation coefficient $(\mathrm{R})$ of 0.66 with a linear regression equation $\hat{Y}=-81,96+0,96 X_{1}+0,77 X_{3}$. The relative contribution of $X_{1}$ is $77.43 \%$ and $X_{3}$ is $22.57 \%$ and the effective contribution $X_{1}$ is $34.22 \%$ and $X_{3}$ is $9.98 \%$.

6. There is a positive and significant relationship between the social environment and independence of learning with mathematics learning outcomes of students of class VIII Odd Semester of SMP Muhammadiyah 9 Yogyakarta 2016/2017 Academic Year. This is indicated by the F test, that is $F_{\text {count }}=5,71 \geq F_{\text {table }}=3,28$. The multiple correlation coefficient $(\mathrm{R})$ of 0.51 with a linear regression equation $\hat{Y}=-54,32+0,81 X_{2}+0,59 X_{3}$. The relative contribution of $\mathrm{X}_{2}$ is $70.31 \%$ and $X_{3}$ is $29.69 \%$ and the effective contribution of $X_{2}$ is $18.08 \%$ and $X_{3}$ is $7.63 \%$.

7. There is a positive and significant relationship between parents' attention, social environment, and learning independence with mathematics learning outcomes of students of class VIII Odd Semester of SMP Muhammadiyah 9 Yogyakarta 2016/2017 Academic Year. This is indicated by the F test, that is $F_{\text {count }}=9,70 \geq F_{\text {table }}=2,90$. The multiple correlation coefficient $(\mathrm{R})$ of 0.69 with a linear regression equation $\hat{Y}=-95,97+0,83 X_{1}+0,41 X_{2}+0,68 X_{3}$ with a double determination coefficient of 0.48 , this means that student mathematics learning outcomes are influenced by parents' attention, social environment, and learning independence by $48 \%$ while $52 \%$ is influenced by other factors not discussed in this study. 


\section{REFERENCES}

Arikunto, Suharsimi. 2012. Dasar-dasar Evaluasi Pendidikan. Jakarta: Bumi Aksara.

Kulsum, Umi dan Mohammad Jauhar. 2014. Pengantar Psikologi Sosial. Jakarta: Prestasi Pustaka. Nurhayati, Eti. 2011. Psikologi Pendidikan Inovatif. Yogyakarta: Pustaka Pelajar.

Sudjana. 2005. Metoda Statistika. Bandung: Tarsito.

Walgito, Bimo. 1986. Bimbingan dan Penyuluhan di Sekolah. Yogyakarta: Andi Offset. 